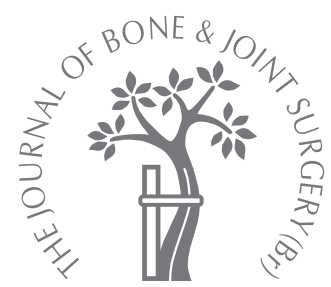

\title{
Fibular centralisation for the reconstruction of defects of the tibial diaphysis and distal metaphysis after excision of bone tumours
}
A. Puri,
B. S. Subin,
M. G. Agarwal
From Tata Memorial
Hospital, Mumbai, India

\begin{abstract}
We evaluated the results of fibular centralisation as a stand alone technique to reconstruct defects that occurred after resection of tumours involving the tibial diaphysis and distal metaphysis.
\end{abstract}

Between January 2003 and December 2006, 15 patients underwent excision of tumours of the tibial diaphysis or distal metaphysis and reconstruction by fibular centralisation. Their mean age was 17 years ( 7 to 40 ). Two patients were excluded; one died from the complications of chemotherapy and a second needed a below-knee amputation for a recurrent giant-cell tumour. A total of 13 patients were reviewed after a mean follow-up of 29 months (16 to 48). Only 16 of 26 host graft junctions united primarily. Ten junctions in ten patients needed one or more further procedure before union was achieved. At final followup 12 of the 13 patients had fully united grafts; 11 walked without aids. The mean time to union at the junctions that united was 12 months ( 3 to 36). The mean Musculoskeletal Tumor Society Score was 24.7 (16 to 30 ).

Fibular centralisation is a durable reconstruction for defects of the tibial diaphysis and distal metaphysis with an acceptable functional outcome. Stable osteosynthesis is the key to successful union. Additional bone grafting is recommended for patients who need postoperative radiotherapy.

Most bone tumours occur in the metaphysis, and resection with an adequate margin generally involves sacrifice of the adjacent joint surface. Most can be reconstructed with a megaprosthesis with an excellent long-term functional result. ${ }^{1,2}$ The outcome of similar treatment in the tibial diaphysis and distal metaphysis has not been as successful, and the use of megaprostheses in this area is therefore limited. ${ }^{3,4}$ Although a below-knee amputation can give an excellent functional result with a modern orthosis, the psychological impact of amputation cannot be underestimated. A variety of procedures have been advocated for the reconstruction of segmental skeletal defects in this area. ${ }^{5-12}$ Fibular centralisation, or the 'fibula-pro-tibia' procedure, has been combined with strut allografts and pasteurised bone. ${ }^{13,14}$ The use of fibular centralisation alone has been well documented in cases of post-traumatic and post-infective tibial defects. ${ }^{15,16}$ Some series have included a few cases where it was used for reconstruction after excision of a tumour. ${ }^{17,18}$ Although Hatori et al $^{19}$ documented a twostage ipsilateral fibular transfer for the tibial defect produced by tumour excision, there has only been one series that chronicled the results of using a one-stage pedicled vascularised fibular graft to arthrodese the ankle after excision of a tumour. ${ }^{20}$

The purpose of this study was to evaluate the results of fibular centralisation alone when used as a single-stage reconstruction technique after the excision of tumours of the diaphysis and distal metaphysis of the tibia.

\section{Patients and Methods}

Between January 2003 and December 2006, 15 tumours of the tibial diaphysis or distal metaphysis were resected and reconstructed by fibular centralisation. These patients were identified by retrospective review of a prospectively maintained database. Their medical records, imaging, and functional status were reviewed. There were ten men and five women, with a mean age of 17 years ( 7 to 40 ). The diagnosis was osteosarcoma in six patients, Ewing's sarcoma in six, and a chondrosarcoma, an adamantinoma and a recurrent giant-cell tumour in one patient each.

One patient with an osteosarcoma died two months after surgery from the complications of chemotherapy. The patient with a recurrent giant-cell tumour had a further recurrence within three months and underwent below- 
Table I. Patient details

\begin{tabular}{|c|c|c|c|c|c|c|c|c|c|c|c|c|c|c|}
\hline Number & $\begin{array}{l}\text { Age } \\
\text { (yrs) }\end{array}$ & Gender & rPathology & $\begin{array}{l}\mathbf{R L}^{*} \\
(\mathbf{c m})\end{array}$ & Arthrodesis & Radiation & $\begin{array}{l}\text { Follow- } \\
\text { up } \\
\text { (mths) }\end{array}$ & $\begin{array}{l}\text { Proximal } \\
\text { implant }\end{array}$ & $\begin{array}{l}\text { Distal } \\
\text { implant }\end{array}$ & $\begin{array}{l}\text { Proximal } \\
\text { union } \\
\text { (mths) }\end{array}$ & $\begin{array}{l}\text { Distal } \\
\text { union } \\
\text { (mths) }\end{array}$ & $\begin{array}{l}\text { Additional } \\
\text { procedures }\end{array}$ & $\begin{array}{l}\text { Current } \\
\text { status }\end{array}$ & MSTS $^{\dagger}$ \\
\hline 1 & 7 & $M$ & Osteosarcoma & 18 & Yes & & 18 & Plate & $\begin{array}{l}\text { Kir- } \\
\text { schner } \\
\text { wire }\end{array}$ & 8 & 4 & $\begin{array}{l}\text { Bone grafting } \\
\text { proximally }\end{array}$ & $\begin{array}{l}\text { United, } \\
\operatorname{LLD}^{\ddagger}=1 \\
\mathrm{~cm}\end{array}$ & 28 \\
\hline 2 & 11 & $M$ & Osteosarcoma & 18 & & & 48 & Plate & Plate & 11 & 11 & & United & 30 \\
\hline 3 & 12 & $\mathrm{~F}$ & Osteosarcoma & 14 & Yes & & 46 & Plate & Plate & 5 & 15 & $\begin{array}{l}\text { Bone grafting } \\
\text { distally }\end{array}$ & $\begin{array}{l}\text { United, } \\
\text { LLD }=1 \\
\mathrm{~cm}\end{array}$ & 27 \\
\hline 4 & 8 & $M$ & $\begin{array}{l}\text { Ewing's } \\
\text { sarcoma }\end{array}$ & 11 & & & 44 & $\begin{array}{l}\text { Kirschner } \\
\text { wire }\end{array}$ & $\begin{array}{l}\text { Kir- } \\
\text { schner } \\
\text { wire }\end{array}$ & 36 & 6 & $\begin{array}{l}\text { Multiple bone } \\
\text { grafting and } \\
\text { internal fixation } \\
\text { proximally }\end{array}$ & United & 29 \\
\hline 5 & 40 & $M$ & $\begin{array}{l}\text { Adam- } \\
\text { antinoma }\end{array}$ & 21 & Yes & & 30 & Screw & $\begin{array}{l}\text { Screw + } \\
\text { Kir- } \\
\text { schner } \\
\text { wire }\end{array}$ & 11 & Nil & & $\begin{array}{l}\text { HTNU } \\
\text { distally. } \\
\text { No treat- } \\
\text { ment }\end{array}$ & 17 \\
\hline 6 & 11 & $M$ & Osteosarcoma & 19 & Yes & & 26 & Screw & $\begin{array}{l}\text { Kir- } \\
\text { schner } \\
\text { wire }\end{array}$ & 8 & 3 & & $\begin{array}{l}\text { United, } \\
\text { LLD }=2 \\
\mathrm{~cm}\end{array}$ & 28 \\
\hline 7 & 10 & $\mathrm{~F}$ & $\begin{array}{l}\text { Ewing's } \\
\text { sarcoma }\end{array}$ & 16 & Yes & Yes & 32 & Plate & Plate & 7 & 30 & $\begin{array}{l}\text { HTNU }^{\S} \text { multiple } \\
\text { bone grafting } \\
\text { and internal } \\
\text { fixation distally. } \\
\text { llizarov fixator }\end{array}$ & $\begin{array}{l}\text { United, } \\
\text { length- } \\
\text { ened } \\
\text { by } 3 \mathrm{~cm}\end{array}$ & 18 \\
\hline 8 & 10 & $M$ & $\begin{array}{l}\text { Ewing's } \\
\text { sarcoma }\end{array}$ & 14 & Yes & Yes & 29 & $\begin{array}{l}\text { Kirschner } \\
\text { wire }\end{array}$ & Plate & 27 & 3 & $\begin{array}{l}\text { HTNU bone } \\
\text { grafting and } \\
\text { internal fixation } \\
\text { proximally. } \\
\text { llizarov fixator }\end{array}$ & $\begin{array}{l}\text { United, } \\
\text { length- } \\
\text { ened } \\
\text { by } 2 \mathrm{~cm} \text {. } \\
\text { On Ili- } \\
\text { zarov } \\
\text { fixator }\end{array}$ & 16 \\
\hline 9 & 15 & $\mathrm{~F}$ & $\begin{array}{l}\text { Ewing's } \\
\text { sarcoma }\end{array}$ & 12 & Yes & Yes & 24 & None & $\begin{array}{l}\text { Kir- } \\
\text { schner } \\
\text { wire }\end{array}$ & 6 & 22 & $\begin{array}{l}\text { HTNU multiple } \\
\text { bone grafting } \\
\text { and internal fix- } \\
\text { ation } \\
\text { distally. Ilizarov } \\
\text { fixator }\end{array}$ & $\begin{array}{l}\text { United, } \\
\text { length- } \\
\text {-ened } \\
\text { by } 2 \mathrm{~cm}\end{array}$ & 18 \\
\hline 10 & 39 & $\mathrm{M}$ & $\begin{array}{l}\text { Chondro- } \\
\text { sarcoma }\end{array}$ & 10 & Yes & & 20 & None & $\begin{array}{l}\text { Kir- } \\
\text { schner } \\
\text { wire }\end{array}$ & 20 & 5 & $\begin{array}{l}\text { HTNU bone } \\
\text { grafting and } \\
\text { internal fixa- } \\
\text { tion proximally }\end{array}$ & United & 25 \\
\hline 11 & 25 & $\mathrm{M}$ & Osteosarcoma & 14 & & & 25 & Plate & Plate & 22 & 3 & $\begin{array}{l}\text { HTNU internal } \\
\text { fixation } \\
\text { proximally }\end{array}$ & United & 27 \\
\hline 12 & 15 & $\mathrm{~F}$ & $\begin{array}{l}\text { Ewing's } \\
\text { sarcoma }\end{array}$ & 17 & & & 16 & Plate & Plate & 16 & 11 & $\begin{array}{l}\text { Bone grafting } \\
\text { and internal } \\
\text { fixation } \\
\text { proximally }\end{array}$ & United & 28 \\
\hline 13 & 13 & $M$ & $\begin{array}{l}\text { Ewing's } \\
\text { sarcoma }\end{array}$ & 14 & & & 24 & Plate & Plate & 4 & 4 & & United & 30 \\
\hline
\end{tabular}

* RL, resection length

† MSTS, musculoskeletal tumor society

¥ LLD, leg-length discrepancy

$\S$ HTNU, hypertrophic nonunion

knee amputation. Both were excluded from the study. A total of 13 patients were reviewed (Table I).

Before surgery all 13 patients had undergone a thorough oncological assessment with staging studies, including plain radiographs and MRI of the limb, CT scans of the chest and whole-body scintigraphy. None had metastases. Each patient received neoadjuvant and adjuvant chemotherapy according to our standard hospital protocol, except for the two with a chondrosarcoma and adamantinoma.

MRI was used to define the extent of the lesion, the involvement of the soft tissues, its relation to the neuro- vascular bundle and the level of transection of the bone. The primary goal of surgery was complete excision of the tumour, with preservation of the limb. A $2 \mathrm{~cm}$ to $3 \mathrm{~cm}$ marrow margin, as calculated on the T1-weighted MRI image, was considered an adequate resection margin. The mean length of resected bone was $15 \mathrm{~cm}$ (10 to 21). In eight cases where the distal metaphysis was involved, the articular surface of the tibia was included in the resection and an arthrodesis was carried out at the time of reconstruction. In the remaining five cases an intercalary joint-preserving resection was possible. 


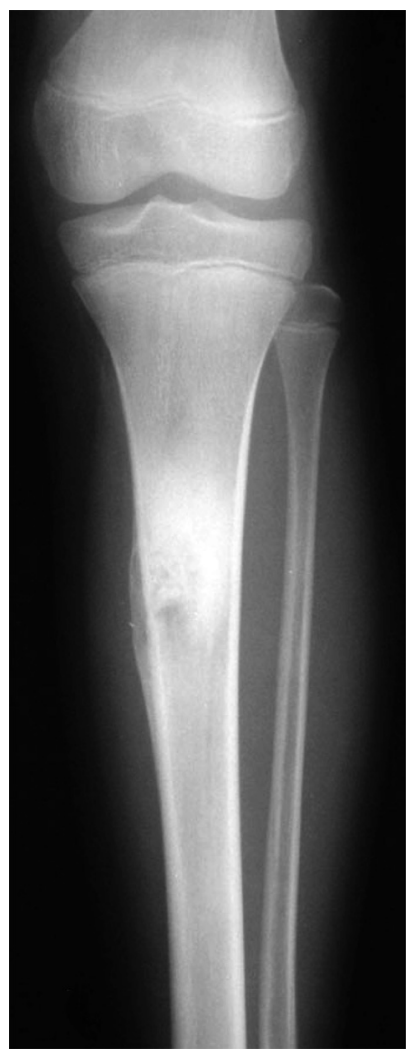

Fig. 1a

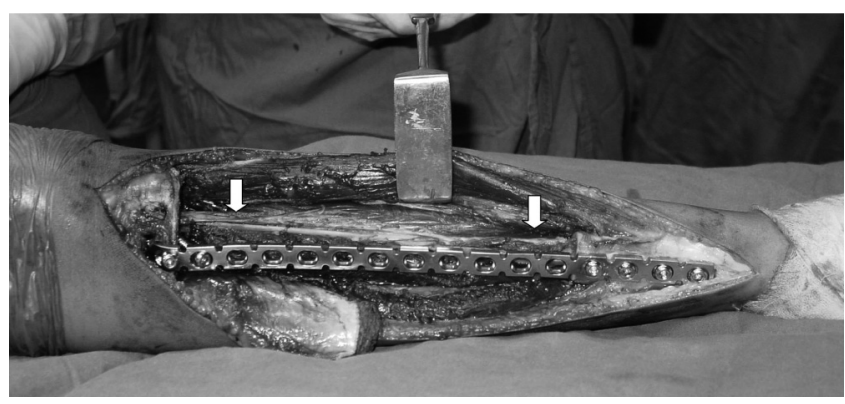

Fig. 1c

a) Pre-operative radiograph showing an osteosarcoma, b) radiograph at 15 months post-operatively showing a contoured reconstruction plate used for fixation and c) intra-operative photograph demonstrating the transposed fibula (white arrows).

Operative technique. After excision of the tibial lesion, an appropriate length of ipsilateral fibula and its retained peroneal muscle attachment is moved medially into the bony defect. The fibula is left $2 \mathrm{~cm}$ to $3 \mathrm{~cm}$ longer than the defect so that both ends can be fitted into the medullary canal of the tibia. In cases where an arthrodesis is needed a notch is created in the talus. Before transposing the fibula care should be taken to ensure that the periosteal sleeve has been completely divided circumferentially around the fibula. After resection of the tibia, the fibular osteotomies are often possible from the medial aspect without having to take an additional lateral incision to expose the fibula. In cases where an arthrodesis is required we occasionally use a small lateral incision at the distal end overlying the tip of the lateral malleolus in order to detach the distal fibular ligaments which otherwise prevent adequate centralisation. We use a combination of plates, screws and Kirschner $(\mathrm{K})$-wires to stabilise the fibula once it had been centralised (Fig. 1).

Of the 26 junctions in 13 patients, plates were used in 14, $\mathrm{K}$-wires in seven, screws in two and a K-wire with a screw in one. No internal fixation was used in two junctions. None of the junctions were bone grafted. Three patients received post-operative radiotherapy. We offer radiotherapy to all patients with a Ewing's sarcoma and a low necrotic fraction on final histopathology, irrespective of the resection margins. Radiotherapy was given at a dose of 45 Gy in 25 fractions.

Post-operatively, patients were allowed to mobilise in a brace or cast. The amount of movement permitted in the adjacent joints depended on the stability of the construct. Protected partial weight-bearing using walking aids progressed to full weight-bearing once there was radiological evidence of bony union. Bridging across three of the four cortices seen on biplanar radiographs was considered evidence of union.

Patients were followed up every three months for the first two years and six-monthly thereafter. They were assessed clinically, and biplanar radiographs of the affected tibia were taken at each visit. Their functional status was assessed at final follow-up using the Musculoskeletal Tumor Society Scoring system. ${ }^{21}$ The mean follow-up was 29 months (16 to 48 ).

\section{Results}

All resection margins were histologically free of disease on intra-operative frozen sections and final analysis. One patient developed a common peroneal palsy which subsequently recovered; otherwise there were no immediate post-operative complications. No infections and no local recurrence were seen in these 13 cases. One patient developed a solitary skeletal metastasis in the opposite distal femur after 24 months. This was resected and reconstructed with a megaprosthesis. He is currently alive without evidence of disease four years after his initial operation.

Of 13 patients, 12 have junctions which have fully united. A total of 11 walk without assistance. One patient has a hypertrophic nonunion of the distal junction and has declined further surgery (Fig. 2). He walks with the aid of a stick. One patient treated with an Ilizarov fixation for a hypertrophic nonunion was also lengthened. Although there is union at the resection margins, the quality of the new bone at the site of lengthening is suspect, and the patient remains in the fixator for five months after application.

Of the 26 junctions, 16 united without further intervention. Two required supplementary bone grafting alone, and four required revision, internal fixation and bone grafting. Three junctions in the three patients who received post- 


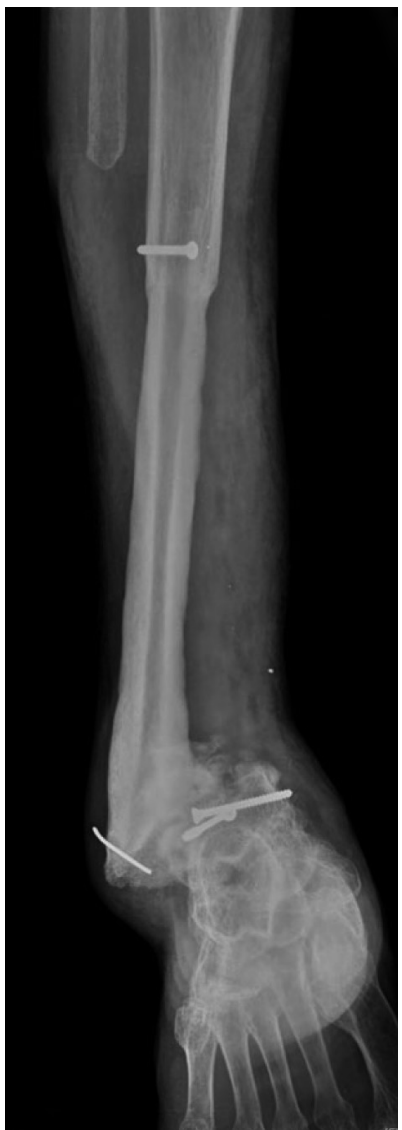

Fig. 2a

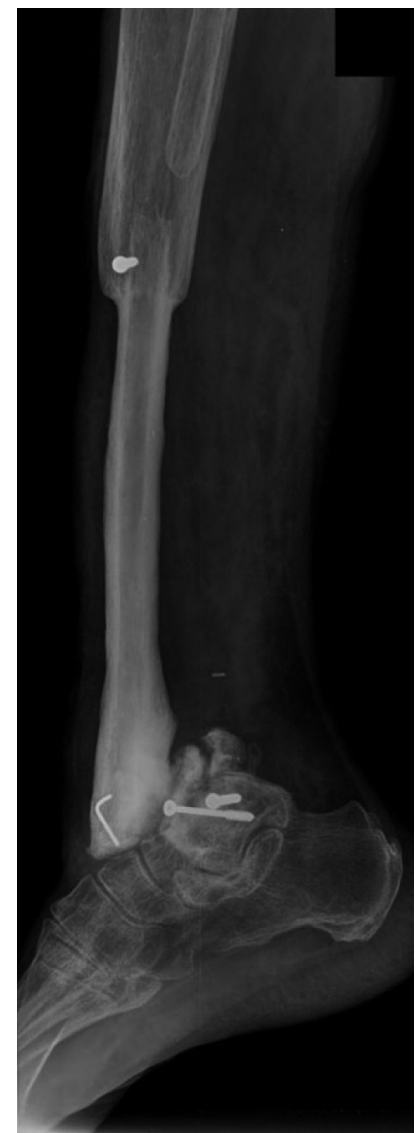

Fig. $2 b$
Radiographs showing hypertrophic nonunion of the distal host-graft junction.

operative radiotherapy required multiple further procedures but eventually united after stabilisation with an Ilizarov fixator. Ten junctions in ten patients required further surgery and six of these showed evidence of instability and hypertrophic nonunion. Two had initially been stabilised with a plate and four with K-wires and/or screws. In the eight cases where an arthrodesis had been attempted a supplementary procedure was required at four of the eight distal junctions. No supplementary procedure was required at the five distal junctions where a joint-preserving intercalary resection had been undertaken.

The mean time to union at the junctions that united was 12 months (3 to 36). All six skeletally-immature patients whose distal tibial epiphysis was resected developed a leglength discrepancy (Table I). The mean Musculoskeletal Tumor Society score was 24.7 (16 to 30). It was a mean of 22 (11 to 28) for those with an arthrodesis and 29 (27 to 30) for those with an intercalary joint-preserving resection.

\section{Discussion}

Reconstructing large defects after resection of a tumour has always been challenging. In tumours involving the tibial diaphysis and distal metaphysis this challenge is often compounded by the absence of adequate soft-tissue cover. $^{12,20}$ Various reconstructive techniques have been used to address this, including large segmental allografts, vascularised or avascular autografts, extracorporeal irradiation and bone transport. ${ }^{5-12}$

Centralisation of the fibula, albeit well accepted for posttraumatic and post-infective tibial defects has not often been used to reconstruct tumour-related defects. There are a few reports describing the fibula-pro-tibia procedure in combination with strut allografts and pasteurised bone. ${ }^{13,14}$ Shalaby et $\mathrm{al}^{12}$ reported three cases of resection arthrodesis, centralisation of the ipsilateral fibula and stabilisation with an Ilizarov frame for osteosarcoma of the distal tibia. Shapiro et $\mathrm{al}^{17}$ included four cases where fibular centralisation was carried out after excision of a tumour. Ebeid et al ${ }^{20}$ have reported the only other large series that mentions onestage fibular transposition and ankle arthrodesis to reconstruct distal tibial defects after excision of a tumour.

When evaluating a reconstruction technique various factors need to be considered including the ease of the procedure, its morbidity, complications, functional outcome and durability.

The use of the avascular strut allograft is often limited by the length of the resection. Strut allografts, albeit a useful option, are limited by their availability and are associated with nonunion, fracture and infection, besides the fear of disease transmission. ${ }^{9,11}$ Distraction osteogenesis requires the prolonged use of external pins and has not, therefore, been widely used in the treatment of patients with malignant bone tumours. ${ }^{22}$ The use of endoprostheses for defects of the distal tibia has been fraught with complications, and their use is therefore limited. ${ }^{3,4}$ Endoprostheses need a certain amount of residual host bone to allow adequate fixation of the stem, and this may often be a limiting factor to their use after resection in tumours involving the tibial diaphysis and distal metaphysis. ${ }^{5}$

Ipsilateral fibular transfer is an easy, inexpensive technique that does not require microvascular skills. It is also quicker to perform than transfers requiring vascular anastomosis. The reduction in volume of the lower leg that follows anteromedial shift of the fibula makes skin closure easier, even in cases where excision of the biopsy scar entails loss of soft tissue. The procedure is restricted to the same limb, unlike those cases in which the opposite fibula is used as a vascularised graft. This helps reduce morbidity. The shorter operating time and the fact that the graft retains its blood supply may help to reduce infection. This can be a major issue in patients who are immunocompromised as a result of adjuvant therapy. The retained vascularity of the graft also improves its chances of union and accelerates the process of hypertrophy. ${ }^{17}$

Our technique of fibular osteotomy differs from that described by Ebeid et al. ${ }^{20}$ They describe a subperiosteal fibular osteotomy which maintains the lateral portion of the periosteum as a continuous sheet from above the proximal osteotomy to below the distal one. We prefer that 


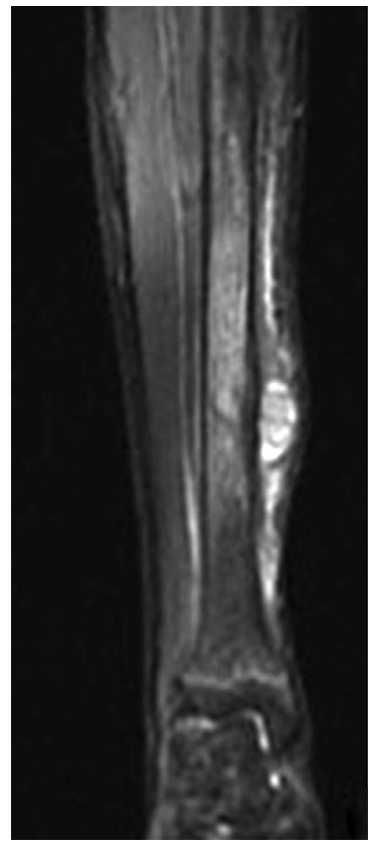

Fig. 3a

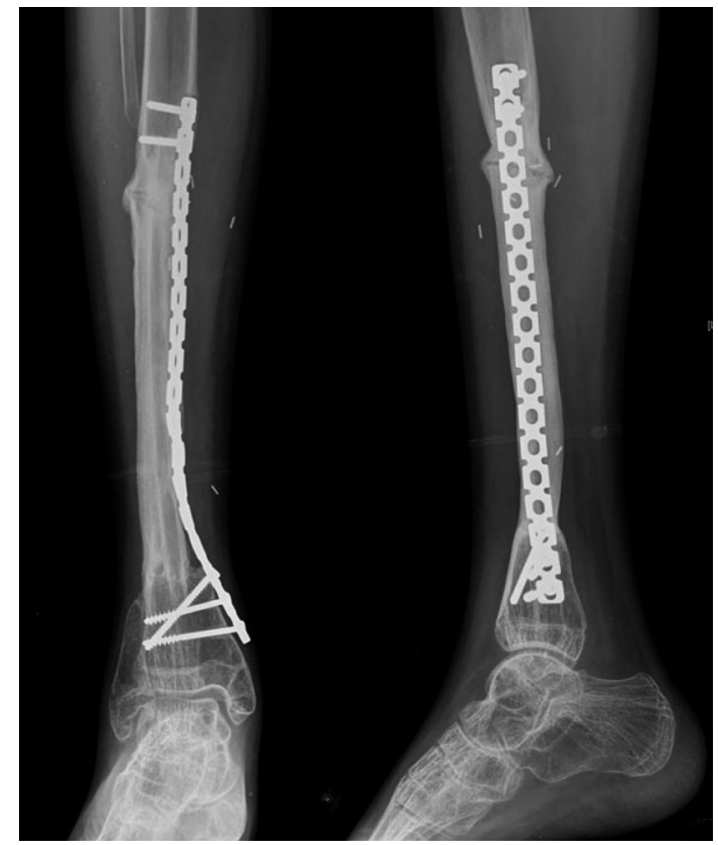

Fig. 3b

a) Pre-operative T1-weighted MRI showing Ewing's sarcoma, b) radiographs showing union with subsequent hypertrophy of the fibula.

the periosteal sleeve be divided transversely around the circumference of the fibula, before it is transposed. In our experience, keeping the periosteum intact laterally often causes it to shear off from the ends of the osteotomised fibula as the fibula is being centralised. This may impair the vascularity of the transposed bone and delay union.

Achieving stability after using a fibular graft for reconstruction can be difficult: stable internal fixation is the key to facilitating union. ${ }^{12,20}$ Ozaki et $\mathrm{al}^{13}$ state that fixation with a long plate and several screws is better than minimal osteosynthesis. In their series, patients who underwent fixation with screws or $\mathrm{K}$-wires suffered a fracture or deformity of the junction, but those with plate fixation had no such complications. Hatori et $\mathrm{al}^{19}$ used little or no internal fixation and reported nonunion as one of the problems in their study. Our series reinforces this observation. Of the ten junctions that needed a second operation, six developed a hypertrophic nonunion. This suggests that the transposed fibula retained its biological potential but lacked stability. Only two of the 14 (14\%) junctions stabilised with a plate were unstable, compared with five of the $12(42 \%)$ junctions with minimal fixation. Consequently, we now use plates wherever possible. The fact that additional procedures were needed at four of the eight $(50 \%)$ distal junctions where an arthrodesis was attempted highlights the difficulty of achieving stable fixation in a small fragment of talus. Custom-made locking plates may help to resolve this issue.

Irradiation impairs healing. ${ }^{9,23}$ In our series, the three patients who received post-operative radiotherapy all required several further operations before the graft united. We now augment our junctions with cancellous autograft or demineralised bone matrix if we suspect that postoperative radiotherapy will be necessary.

There has been some reluctance to use the fibula on its own, as some authorities believe it to be unable to withstand the stresses of weight-bearing. ${ }^{14}$ We did not encounter any stress fractures in our small series. Our rehabilitation schedule does not depend on hypertrophy of the fibula; patients progressed to full weight-bearing once there was radiological evidence of bony union. Hypertrophy was seen later after continued weightbearing. Hatori et $\mathrm{al}^{19}$ and Ebeid et $\mathrm{al}^{20}$ saw fibular hypertrophy in each of their cases, and Krieg and Hefti ${ }^{23}$ showed that this occurred more commonly in younger patients; fatigue fractures were uncommon when a bypassing plate had been used. All except three of our patients were aged 15 years or younger. This could explain why a single fibula provided adequate structural support (Fig. 3). Stress fractures may occur in adults, but are often asymptomatic or can be managed conservatively. ${ }^{19,23}$ Although it is possible to increase the strength of the construct with a strut allograft, we are reluctant to advocate this in all cases. First, allografts of an appropriate size are not always available, and second, soft-tissue closure can be a problem because of the difficulties in closing poor quality tissues over a relatively large construct.

Leg-length discrepancy is inevitable if the distal tibial epiphysis is resected. Fortunately, it is not a major contributor to limb length, and the discrepancy is less than that seen 
with resections around the knee. ${ }^{20}$ Our three patients who needed to be stabilised with an Ilizarov fixator were lengthened by between $2 \mathrm{~cm}$ and $3 \mathrm{~cm}$. The other three currently have a leg-length discrepancy of less than $2 \mathrm{~cm}$, but may need to be lengthened in the future.

The time to union and the functional results in our series are comparable to those seen with other techniques. $5,9,10,12$ Patients with an arthrodesis had a poorer functional outcome than those with a joint-preserving resection. This may be because some needed several further procedures at the distal junction to achieve union. The three patients who needed radiotherapy all had an arthrodesis and are included in this group. The four patients who had an arthrodesis but did not need further surgery had a functional outcome comparable to that achieved with a jointpreserving resection.

The reconstruction of a large defect resulting from resection of a tumour has always been difficult. In the tibia, reconstruction by fibular centralisation has proved to be a durable option with an acceptable functional outcome. Stable osteosynthesis is the key to union. The appropriate use of custom-made locking plates and supplementary cancellous bone grafting at the outset may reduce the number of further operations currently recorded to achieve union.

No benefits in any form have been received or will be received from a commercial party related directly or indirectly to the subject of this article.

\section{References}

1. Myers GJC, Abudu AT, Carter SR, Tillman RM, Grimer RJ. Endoprosthetic replacement of the distal femur for bone tumours: long-term results. J Bone Joint Surg [Br] 2007:89-B:521-6.

2. Myers GJC, Abudu AT, Carter SR, Tillman RM, Grimer RJ. The long-term results of endoprosthetic replacement of the proximal tibia for bone tumours. J Bone Joint Surg [Br] 2007;89-B:1632-7.

3. Abudu A, Grimer RJ, Tillman RM, Carter SR. Endoprosthetic replacement of the distal tibia and ankle joint for aggressive bone tumours. Int Orthop 1999;23:291-4

4. Natarajan MV, Annamalai K, Williams S, Selvaraj R, Rajagopal TS. Limb salvage in distal tibial osteosarcoma using a custom mega prosthesis. Int Orthop 2000;24:282-4

5. AhImann ER, Menendez LR. Intercalary endoprosthetic reconstruction for diaphyseal bone tumours. J Bone Joint Surg [Br] 2006;88-B:1487-91
6. Ofiram E, Liebergall M, Porat S, Peyser A, Mosheiff R. "Tibialization" of the fibula in the treatment of severe tibial bone loss. Foot and Ankle Surgery 2002;8:191-5.

7. Tunn PU, Moesta TK, Delbrück H. Bilateral fibula graft: biological reconstruction following resection of malignant bone tumours. Chirurg 2006;77:919-25 (in German).

8. Laffosse JM, Accadbled F, Abid A, et al. Reconstruction of long bone defects with a vascularized fibular graft after tumor resection in children and adolescents: thirteen cases with 50-month follow-up. Rev Chir Orthop Reparatrice Appar Mot 2007:93:55563 (in French)

9. Ramseier LE, Malinin TI, Temple HT, Mnaymneh WA, Exner GU. Allograft reconstruction for bone sarcoma of the tibia in the growing child. J Bone Joint Surg [Br] 2006;88-B:95-9.

10. Chen TH, Chen WM, Huang CK. Reconstruction after intercalary resection of malignant bone tumours: comparison between segmental allograft and extracorporeally-irradiated autograft. J Bone Joint Surg [Br]2005;87-B:704-9.

11. Musculo DL, Ayerza MA, Aponte-Tinao L, Ranalletta M, Abalo E. Intercalary femur and tibia segmental allografts provide an acceptable alternative in reconstructing tumor resections. Clin Orthop 2004;426:97-102.

12. Shalaby S, Shalaby H, Bassiony A. Limb salvage for osteosarcoma of the distal tibia with resection arthrodesis, autogenous fibular graft and llizarov external fixator. J Bone Joint Surg [Br] 2006;88-B:1642-6.

13. Ozaki T, Hillmann A, Wuisman P, Winkelmann W. Reconstruction of tibia by ipsilateral vascularised fibula and allograft: 12 cases with malignant bone tumors. Acta Orthop Scand 1997:68:298-301.

14. Ozaki T, Fujiwara K, Kunisada T, et al. Reconstruction with ipsilateral fibula transfer with pasteurized bone after excision of bone sarcoma of the tibia. Sarcoma 2004;8:97-102.

15. De Meulemeester $\mathbf{C}$, Verdonk R, Bongaerts $\mathbf{W}$. The fibula pro tibia procedure in the treatment of nonunion of the tibia. Acta Orthop Belg 1992;58(Suppl 1):187-9.

16. Chacha PB, Ahmed M, Daruwalla JS. Vascular pedicle graft of the ipsilateral fibula for non-union of the tibia with a large defect: an experimental and clinical study. J Bone Joint Surg [Br] 1981;63-B:244-53.

17. Shapiro MS, Endrizzi DP, Cannon RM, Dick HM. Treatment of tibial defects and nonunions using ipsilateral vascularized fibular transposition. Clin Orthop 1993:296:207-12.

18. Hertel R, Pisan M, Jakob RP. Use of the ipsilateral vascularised fibula for tibial reconstruction. J Bone Joint Surg [Br] 1995;77-B:914-19.

19. Hatori M, Ayoub KS, Grimer RJ, Carter SR, Tillman RM. The two-stage ipsilateral fibular transfer for tibial defect following tumour excision. Sarcoma 2000;4:27-30

20. Ebeid W, Amin S, Abdelmegid A, Refaat Y, Ghoneimy A. Reconstruction of distal tibial defects following resection of malignant tumours by pedicled vascularised fibular grafts. Acta Orthop Belg 2007:73:354-9.

21. Enneking WF, Dunham W, Gebhardt MC, Malawar M, Pritchard DJ. A system for the functional evaluation of reconstructive procedures after surgical treatment of tumors of the musculoskeletal system. Clin Orthop 1993;286:241-6.

22. Ozaki T, Nakatsuka Y, Kunisada T, et al. High complication rate of reconstruction using llizarov bone transport method in patients with bone sarcomas. Arch Orthop Trauma Surg 1998;118:136-9.

23. Krieg AH, Hefti F. Reconstruction with non-vascularised fibular grafts after resection of bone tumours. J Bone Joint Surg [Br] 2007;89-B:215-21. 